\title{
Bilateral Internuclear Ophthalmoplegia in a Patient with Devic's Neuromyelitis Optica
}

\author{
E. Garcia-Martin ${ }^{\mathrm{a}} \quad$ I. Pinilla ${ }^{\mathrm{a}} \quad$ V. Pueyo ${ }^{\mathrm{a}} \quad$ L. Gil ${ }^{\mathrm{a}}$ \\ J. Martinez-Morales ${ }^{\mathrm{b}} \quad$ J. Fernandez ${ }^{\mathrm{a}}$
}

aDepartment of Ophthalmology, Hospital Universitario Miguel Servet, Instituto Aragonés de Ciencias de la Salud, Zaragoza, and bepartment of Ophthalmology, San Jorge Hospital, Huesca, Spain

\section{Key Words}

Devic's neuromyelitis optica · Bilateral internuclear ophthalmoplegia - Visual loss . Retrobulbar neuritis · Nystagmus

\begin{abstract}
An unusual presentation of Devic's neuromyelitis optica (NMO) disease associated with bilateral internuclear ophthalmoplegia (INO) is described. A 32-year-old pregnant patient was diagnosed with NMO. First symptoms were headache and sudden visual loss in her right eye (RE). Eighteen months ago, she reported other neurologic symptoms such as paresthesia. Based on her visual field, fundoscopy and Ishihara test, she was diagnosed with retrobulbar neuritis of the RE. After delivery, new neurologic symptoms resembling transverse myelitis appeared. She was treated with methylprednisolone and plasmapheresis, which improved her visual acuity; however, a sudden bilateral INO appeared, with adduction defect and nystagmus with abduction in both eyes. No improvement was obtained after treatment with azathioprine and rituximab. Paresis of the legs and the right arm persisted, but double vision and OIN gradually disappeared. At the end, the patient had a residual exophoria in the RE and nystagmus with abduction in the left eye. Prevalence of NMO is lower than one case per one million inhabitants, and it is not likely to affect the encephalic trunk; furthermore, bilateral INO in NMO is rare. Two major criteria and at least two of the three minor ones are required to confirm a NMO diagnosis, and our patient fulfilled these diagnosis criteria.
\end{abstract}




\begin{tabular}{c|l|l|l}
$\begin{array}{c}\text { Case Reports in } \\
\text { NeUlology }\end{array}$ & $\begin{array}{l}\text { Case Rep Neurol 2010;2:139-144 } \\
\text { DOI: 10.1159/000322428 }\end{array}$ & $\begin{array}{l}\text { Published online: } \\
\text { November 12, 2010 }\end{array}$ & $\begin{array}{l}\text { O 2010 S. Karger AG, Basel } \\
\text { ISSN 1662-680X } \\
\text { www.karger.com/crn }\end{array}$ \\
\hline
\end{tabular}

\section{Introduction}

Devic's disease, also known as neuromyelitis optica (NMO), is an autoimmune and inflammatory disorder that combines optic neuropathy and acute or subacute transverse myelitis which may occur simultaneously or after some time [1].

The main symptoms of Devic's disease are visual loss and spinal cord dysfunction. The typical presentation of optic neuritis is visual impairment with acute decrease of visual acuity. Brainstem affection can lead to a sensitivity reduction, muscle weakness and loss of bladder and bowel control [2], although unusual conditions as hiccups [3] or narcolepsia [4] have also been reported. The most common neurological symptoms are legs or limbs weakness (paraparesis or tetraparesis) with sensorial signs.

The origin of NMO, since Devic defined it in 1870, was unknown and some authors thought that it was a variant of multiple sclerosis (MS). In the last years, NMO-IgG antibodies have been described as the physiopathological cause of Devic's disease [5]. The antibodies' target is aquaporin 4 , a protein which acts as a water transport channel across the astrocyte cell membrane [6]. The function of aquaporin 4 is important for the maintenance of the blood-brain barrier [7].

Immunosuppressive treatments for NMO have a low effectiveness and prognosis is poor with some cases having an acute and devastating evolution [8]. Intravenous corticosteroids, as methylprednisolone, are usually used to treat new attacks of optic neuritis or myelitis. Some authors have reported little evidence for immunosuppressive treatment in $\mathrm{NMO}$, especially using mitoxantrone, azathioprine and mycophenolate mofetil $[9,10]$.

Internuclear ophthalmoplegia (INO) is a disorder affecting eye movements caused by medial longitudinal fasciculus affection. Patients affected by INO present nystagmus in one eye when the other eye is in abduction, and it can also cause diplopia. MS is by far the most common cause of INO. Usually, INO is unilateral, but it can also affect both sides [11].

We present a case of a woman diagnosed with NMO who had acute and bilateral INO and tetraparesis without response to immunosuppressive treatments.

\section{Case Report}

A 32-year-old pregnant woman at 34 weeks' gestation presented to the emergency department complaining of headache and sudden reduction of visual acuity in her RE to counting fingers at one meter. Her medical history revealed neurologic symptoms as paresthesia of the legs and the right arm 18 months ago.

At the visual field exam, altitudinal and centrocecal defects were observed. The patient was diagnosed with retrobulbar neuritis in the RE with an abnormal Ishihara test, a relative afferent pupillary defect in the RE and normal fundoscopy. Seven days later, RE visual acuity improved to 5/100, pupillary reflexes and Ishihara test were normal and the visual field scotoma decreased. One month after the initial episode, eye evaluation was normal and visual acuity in the RE was 7/10. Two days after delivery, she experienced paraparesis and L'hermitte's sign. Repeated blood cultures for common pathogens and mycobacteria were negative. Serologic testing for human immunodeficiency virus, human T-lymphotrophic virus, cytomegalovirus, herpes simplex viruses, poliomyelitis and tetanus resulted negative. Antinuclear antibodies and antineutrophil cytoplasmic antibodies were negative, but anti-DNA antibodies were elevated. Hemogram and biochemistry were normal. 
Brain magnetic resonance images (MRI) showed no alterations, but a longitudinal lesion that affected four segments was seen in the cervical spinal cord MRI (fig. 1).

Empirical therapy with methylprednisolone $1 \mathrm{~g}$ /day during 3 days (Solumoderin ${ }^{\circledR}$; Pfizer, Madrid, Spain) and azathioprine (Imurel ${ }^{\circledR}$; Glaxo-Welcome, Paris, France) was administered, but the patient's neurologic status remained stable. No abnormalities were seen on a second brain MRI.

Three months later, paraparesis improved, but the patient was admitted to the hospital with abdominal pain and fever without response to antibiotic therapy (amoxicillin-clavulanic 875/125 mg). Two days after admission, she presented acute tetraplegia with loss of sensibility in the cervical area, Babinsky sign and areflexia of both legs and of her right arm. The combined anti-infective and steroid therapy was administered with absence of clinical improvement. As the patient did not respond to the previous treatments, plasmapheresis for 15 consecutive days was performed without initial efficacy [12]. Afterwards, a progressive and slow improvement of neurologic symptoms was observed.

Two months later, the patient presented an acute limitation in adduction of both eyes and bilateral nystagmus in abduction which was diagnosed as bilateral INO (online suppl. video 1, www.karger.com/doi/10.1159/000322428) (fig. 2a, b). A new spinal cord MRI showed brainstem necrosis that affected the encephalic trunk. Two intravenous injections $(1 \mathrm{~g})$ of rituximab (Rituxan ${ }^{\circledR}$; Genentech Inc., San Francisco, Calif., USA, 2008), an anti-CD20 monoclonal antibody, separated by 2 weeks in combination with methotrexate were administered to the patient [13]. Suddenly, her systemic state worsened and she presented hallucinations and astonishment, needing intravenous nutrition and bladder catheter.

After six months, the patient was still at the hospital with bilateral paresis of the right arm and leg. Double vision and INO disappeared, but residual nystagmus of the RE and limitation in adduction of the LE persisted (online suppl. video 2). Visual acuity was 9/10 in both eyes; pupilar reflex, Ishihara test, visual field and eye fundus were normal. Optical coherence tomography (Stratus OCT 3000; Carl Zeiss Meditec, Dublin, Calif., USA) showed slight reduction of the retinal nerve fiber layer (RNFL) thickness in the superior and nasal area of the RE and an increase of the RNFL in the superior quadrant of the LE (fig. 3).

\section{Discussion}

The spinal cord damage in NMO can range from inflammatory demyelination to necrotic damage of the white and grey matter $[6,14]$. Inflammation may also affect the brain and sometimes neurologic symptoms suggest acute disseminated encephalomyelitis or MS [15].

In 2006, the Mayo Clinic proposed a revised set of criteria for the diagnosis of Devic's disease [16]. Our patient fulfilled the two major criteria and two of the three supportive criteria: brain MRI not meeting criteria for MS at disease onset, and spinal cord MRI with contiguous T2-weighted signal abnormality extending over three or more vertebral segments. She was seronegative for NMO-IgG, but the presence of anti-DNA antibodies suggests an autoimmune disease such as NMO. Some patients with NMO may be negative for NMO-IgG, while some patients with NMO-IgG may not fulfill clinical criteria for NMO $[2,17]$.

INO is an unusual presentation in a patient with NMO. Typically, the disease affects the brainstem, but not the brain nerves; however, unusual conditions of the brain nerves in NMO have been reported $[18,19]$. 


\begin{tabular}{|c|c|c|c|}
\hline $\begin{array}{l}\text { Case Reports in } \\
\text { Nellooys }\end{array}$ & $\begin{array}{l}\text { Case Rep Neurol 2010;2:139-144 } \\
\text { DOI: } 10.1159 / 000322428\end{array}$ & $\begin{array}{l}\text { Published online: } \\
\text { November 12, } 2010\end{array}$ & $\begin{array}{l}\text { ( ) } 2010 \text { S. Karger AG, Basel } \\
\text { ISSN } 1662-680 X \\
\text { www.karger.com/crn }\end{array}$ \\
\hline
\end{tabular}

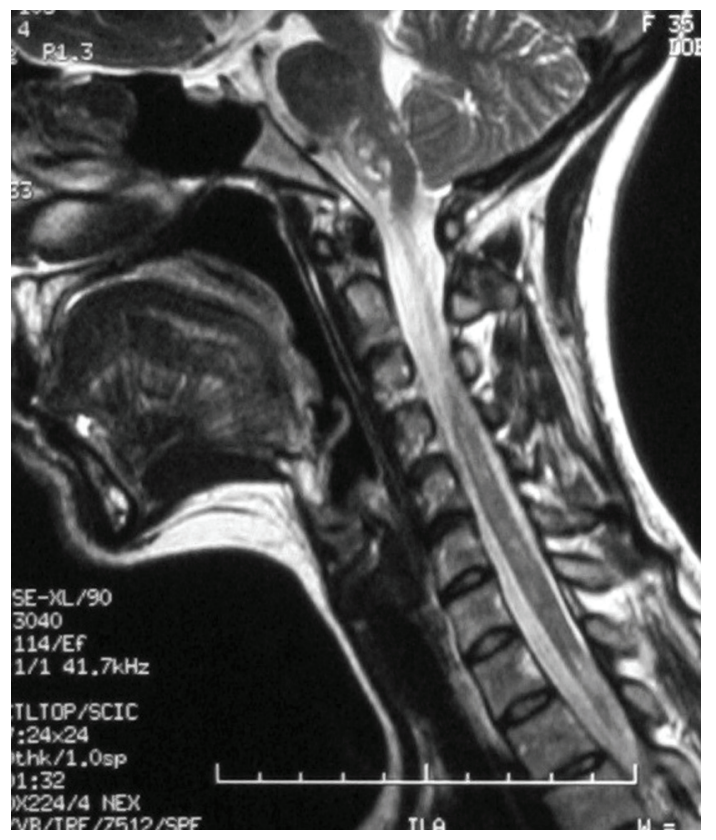

Fig. 1. Cervical spinal MRI showing a longitudinal lesion affecting four segments.
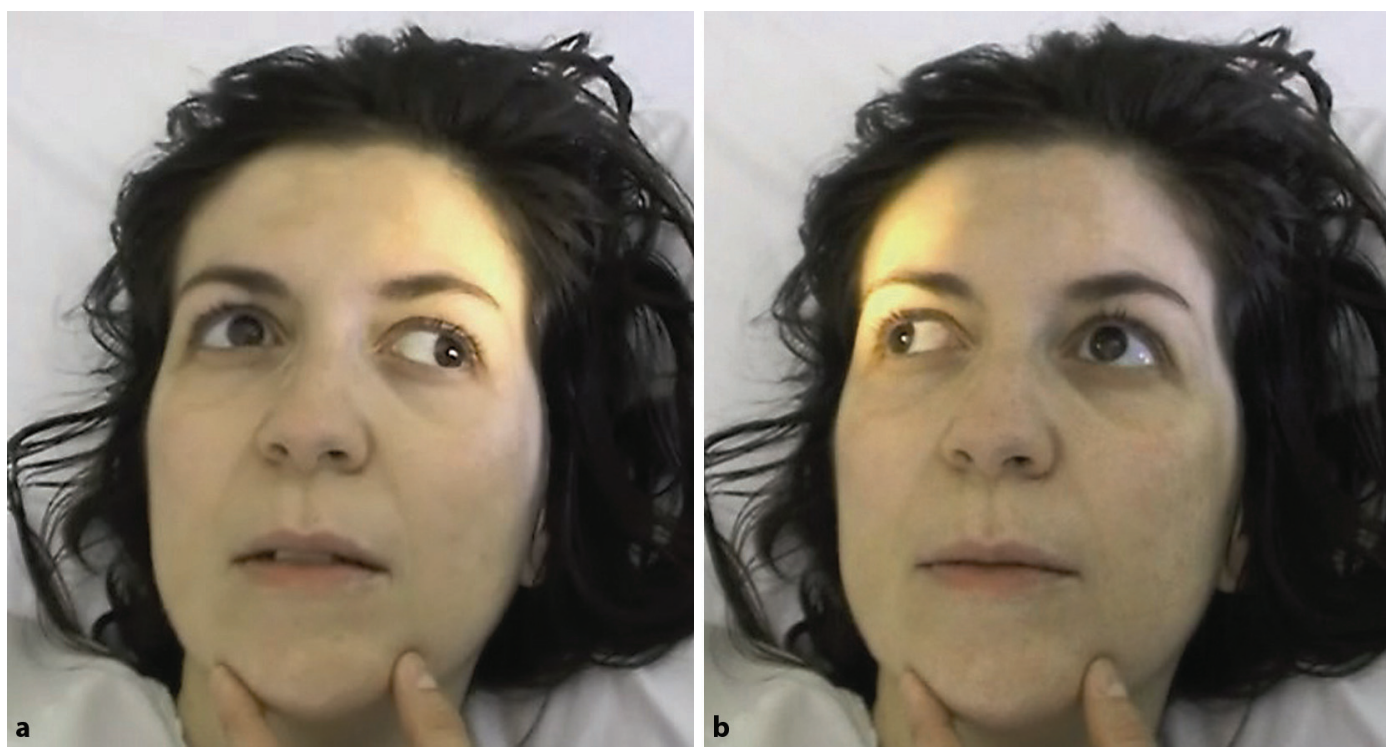

Fig. 2. a, b Eye movements showing limitation in adduction of both eyes and bilateral nystagmus in abduction. The cover/uncover and alternate cover test showed an alternating exotrophia (the outturned eye refixates inward when the other is covered). 


\begin{tabular}{l|l|l|l} 
Case Reports in & $\begin{array}{l}\text { Case Rep Neurol 2010;2:139-144 } \\
\text { DOl: 10.1159/000322428 }\end{array}$ & $\begin{array}{l}\text { Published online: } \\
\text { November 12, 2010 }\end{array}$ & $\begin{array}{l}\odot \text { ISSN 1662-680X } \\
\text { www.karger.com/crn }\end{array}$ \\
\hline
\end{tabular}
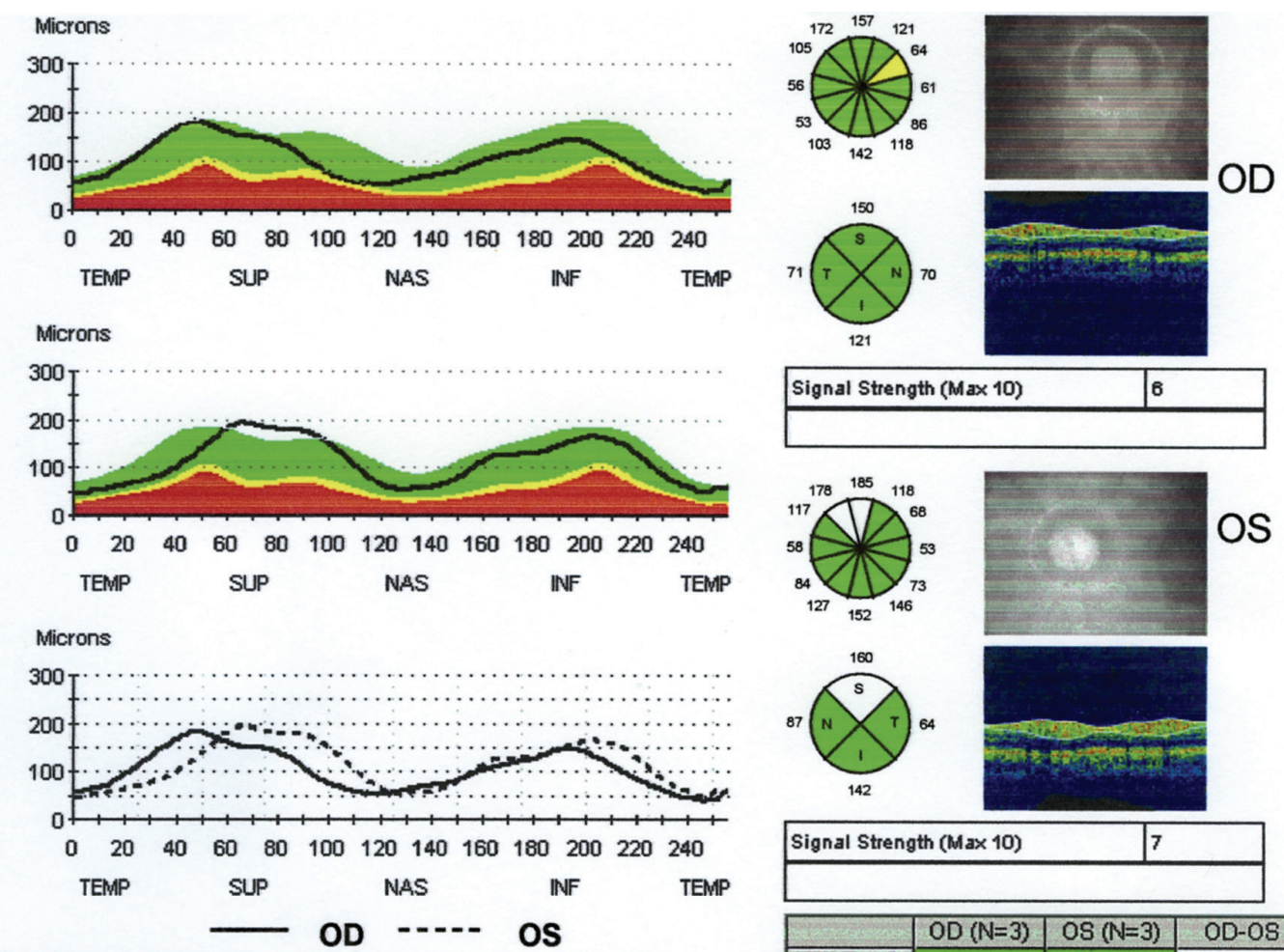

\begin{tabular}{|c|c|c|c|}
\hline \multicolumn{2}{|c|}{ Signal Strength $(\operatorname{Max} 10)$} & \multicolumn{2}{|c|}{7} \\
\hline & $\mathrm{OD}(\mathrm{N}=3)$ & $\operatorname{OS}(\mathrm{N}=3)$ & $\mathrm{OD}-0 \mathrm{~S}$ \\
\hline Imaxismax & 0.80 & 0.86 & -0.06 \\
\hline Smaxilmax & 1.25 & 1.17 & 0.09 \\
\hline Smaxtavg & 2.58 & 3.00 & -0.42 \\
\hline ImaxTavg & 2.06 & 2.57 & -0.51 \\
\hline SmaxiNavg & 2.60 & 2.23 & 0.37 \\
\hline Max-Min & $\overline{143.00}$ & $\overline{149.00}$ & -6.00 \\
\hline Smax & 183.00 & 193.00 & -10.00 \\
\hline Imax & 146.00 & 166.00 & -20.00 \\
\hline Savg & 150.00 & 160.00 & -10.00 \\
\hline lavg & 121.00 & 142.00 & -21.00 \\
\hline Avg.Thick & 103.03 & 113.24 & -10.21 \\
\hline
\end{tabular}

Fig. 3. Optical coherence tomography showing slight reduction of the RNFL thickness in the superior and nasal quadrants of the RE and an increase of RNFL in the superior quadrant of the LE.

\section{References}

1 Daza J, Roncallo A: Neuromielitis óptica: Estado del arte. Revista Salud Uninorte 2007;23:204-219.

2 Mayo Clinic: Devic's Disease Symptoms (accessed March 11, 2008).

3 Takahashi T, Miyazawa I, Misu T, Takano R, Nakashima I, Fujihara K, et al: Intractable hiccup and nausea in neuromyelitis optica with anti-aquaporin- 4 antibody: a herald of acute exacerbations. Neurol Neurosurg Psychiatry 2008;79:1075-1078.

4 Kanbayashi T, Shimohata T, Nakashima I, Yaguchi H, Tabe I, Nishizawa M, et al: Symptomatic narcolepsy in patients with neuromyelitis optica and multiple sclerosis: new neurochemical and immunological implications. Archives of Neurology 2009;66:1563-1566.

5 Cross SA: Rethinking neuromyelitis optica (Devic disease) J Neuroophthalmol 2007;27:57-60.

6 Wingerchuk DM: Neuromyelitis optica. The International MS Journal 2006;13:42-50.

7 Minagar A, Alexander JS, Fowler MR, Long AC, Kelley RE: Devic disease: clinical course, pathophysiology, and management. Pathophysiology 2002;9:33-40. 
8 Klawiter EC, Alvarez E, Xu J, Paciorkowski AR, Zhu L, Parks BJ, et al: NMO-IgG detected in CSF in seronegative neuromyelitis optica. Neurology 2009;72:1101-1103.

9 Jacob A, Matiello M, Weinshenker BG, Wingerchuk DM, Lucchinetti C, Shuster E, et al: Treatment of neuromyelitis optica with mycophenolate mofetil: retrospective analysis of 24 patients. Arch Neurol 2009;66:1128-1133.

10 Weinstock-Guttman B, Ramanathan M, Lincoff N, Napoli SQ, Sharma J, Feichter J, et al: Study of mitoxantrone for the treatment of recurrent neuromyelitis optica (Devic disease). Arch Neurol 2006;63:957963.

11 Chalumeau-Lemoine L, Chretien F, Si Larbi AG, Brugieres P, Gray F, Brun-Buisson C, et al: Devic disease with brainstem lesions. Arch Neurol 2006;63:591-593.

12 Wingerchuk D: Neuromyelitis Optica (Devic's Syndrome). Rare Neuroimmunologic Disorders Symposium 2006. (accessed January 5, 2007).

13 Cree BAC, Lamb S, Morgan K, Chen A, Waubant E, Genain C: An open label study of the effects of rituximab in neuromyelitis optica. Neurology 2005;64:1270-1272.

14 Lucchinetti CF, Mandler RN, McGavern D, Bruck W, Gleich G, Ransohoff RM, et al: A role for humoral mechanisms in the pathogenesis of Devic's neuromyelitis optica. Brain 2002;125:1450-1461.

15 Garg RK: Acute disseminated encephalomyelitis. Postgraduate Medical Journal 2003;79:11-17.

16 Wingerchuk DM, Pittock SJ, Lennon VA, et al: Neuromyelitis optica diagnostic criteria revisited: validation and incorporation of the NMO-IgG serum autoantibody. Neurology 2006;66:1485-1489.

17 Roemer SF, Parisi JE, Lennon VA, Benarroch EE, Lassmann H, Bruck W, et al: Pattern-specific loss of aquaporin-4 immunoreactivity distinguishes neuromyelitis optica from multiple sclerosis. Brain 2007;130:1194-1205.

18 Fardet L, Généreau T, Mikaeloff Y, Fontaine B, Seilhean D, Cabane J: Devic's neuromyelitis optica: study of nine cases. Acta Neurol Scand 2003;108:193-200.

19 Da Silva Costa RM, Santos AC, Costa LS: An unusual chiasmal visual defect in a patient with neuromyelitis optica: case report. Arq Bras Oftalmol 2007;70:153-155. 